\title{
ZAGOVARANJE ZA KNJIŽNICE I PARTNERSTVO ZA ODRŽIVI RAZVOJ
}

\author{
LIBRARY ADVOCACY \\ AND PARTNERSHIP FOR SUSTAINABLE DEVELOPMENT
}

\author{
Edita Bačić \\ Pravni fakultet \\ Sveučilište u Splitu \\ edita@pravst.hr
}

\author{
UDK / UDC 02: 316.334 .55 \\ Stručni rad / Professional paper \\ Primljeno / Received: 6. 11. 2018. \\ Prihvaćeno / Accepted: 21. 1. 2019.
}

\section{Sažetak}

Cilj. Ukazati na važnost i potrebu sustavnog javnog zagovaranja za knjižnice temeljenog na vrijednostima knjižničarske profesije, interesima javnog dobra i ciljevima održivog razvoja. U radu se govori i o mogućoj suradnji knjižničarskih društava u implementaciji ciljeva UN-ove Agende 2030 u nacionalnim i međunarodnim okvirima. Posebno je istaknuta važnost aktivnog djelovanja knjižničarske zajednice i svih zainteresiranih javnih zagovarača na donosioce odluka vezano uz njihovu podršku knjižnicama i održivom razvoju.

Metodologija. Propituju se međunarodna iskustva i primjeri dobre prakse u hrvatskom knjižničarstvu, kao i razvojne mogućnosti novih partnerskih projekata kroz postojeću regionalnu suradnju knjižničarskih društava uz poseban osvrt na IFLA-in Međunarodni program javnog zagovaranja (IFLA International Advocacy Programme - IAP).

Rezultati. U radu se ukazuje na potrebu sustavnog dokumentiranja usluga u svim vrstama knjižnica koje svojim djelovanjem doprinose ostvarivanju ciljeva održivog razvoja. Potvrdu tih promišljanja nalazimo u praksi međunarodne knjižničarske zajednice, posebno u radu International Federation of Library Associations (IFLA).

Vjesnik bibliotekara Hrvatske 61, 2(2018), 367-380

ISSN 0507-1925

(C) VBH 2018. 
Praktična primjena i društveni značaj. Svrha usvajanja vještina javnog zagovaranja jest stvaranje uvjeta za što učinkovitije javno djelovanje knjižničara prilikom zastupanja interesa njihovih korisnika i interesa šire društvene zajednice. Promatrano u globalnim okvirima, danas je to važno s aspekta uloge knjižnica u implementaciji ciljeva UN-ove Agende 2030 za koju se zalaže cijela međunarodna zajednica, uključujući Republiku Hrvatsku.

Originalnost/vrijednost. Namjera je autora upoznati hrvatsku profesionalnu zajednicu s aktualnim trendovima u međunarodnom povezivanju knjižnica i primjerima dobre prakse u zagovaranju njihove uloge u implementaciji UN-ove Agende 2030. U tom kontekstu ostvarivanja partnerstva neophodno je razviti savjetodavni odnos sa širom društvenom zajednicom i državnim tijelima na nacionalnoj razini.

Ključne riječi: IFLA-in Međunarodni program javnog zagovaranja, partnerstvo za održivi razvoj, regionalna suradnja, zagovaranje za knjižnice, UN-ova Agenda 2030.

\begin{abstract}
Objective. The aim of the paper is to highlight the importance and the need for a systematic public advocacy for libraries based on the values of the library profession, the interests of the public good, and the goals of sustainable development. The paper also discusses the possible cooperation of librarians in the implementation of the goals of the UN Agenda 2030 within the national and international frameworks. The paper emphasizes the importance of the active participation of the library community and all other interested public advocates on the decision-makers regarding their support to libraries and sustainable development.
\end{abstract}

Methodology. A number of the international experiences and examples of good practice in Croatian librarianship as well as the development possibilities of new partner projects are being examined through the existing regional cooperation of librarians, with special reference to the IFLA International Advocacy Program (IAP).

Results. The paper points to the need for systematic documentation of services in all types of libraries that contribute to achieving the goals of sustainable development through their actions. The confirmation of these considerations is found in the practice of the international library community, especially in the work of the International Federation of Library Associations (IFLA).

Practical application and social significance. The purpose of adopting public advocacy skills is to create the conditions for the most effective public activity of librarians in representing the interests of their users and the interest of the wider community. If observed in the global context, the role of libraries in implementing the UN Agenda 2030's goals is particularly important, especially considering that the entire international community, including the Republic of Croatia, is committed to it. 
Originality / Value. The author intends to acquaint the Croatian professional community with the current trends in the international linking of libraries and present some examples of good practice in advocating their role in the implementation of the UN Agenda 2030. In the context of achieving partnership, it is necessary to develop an advisory relationship with the wider social community and the state institutions at the national level.

Keywords: library advocacy, IFLA International Advocacy Programme, partnership for sustainable development, regional cooperation, UN Agenda 2030

\section{Vrijednosti knjižničarske profesije - zalog povjerenja šire društve- ne zajednice}

Međunarodna knjižničarska zajednica raznolika je i obuhvaća djelatnike raznih profila koji zajedno s knjižničarima unapređuju službe i usluge u knjižnicama, ali svi oni ne spadaju u redove stručnog knjižničarskog osoblja. Stručni djelatnici imaju specijalističko znanje potrebno za obavljanje knjižničarske profesije, u prvom redu organizirano školovanje i mogućnost stalnog stručnog usavršavanja, što je praksa u većini zemalja. Iako postoji više značajki koje neko zanimanje čine profesijom, stručnjaci se uglavnom slažu da su za to presudni sljedeći uvjeti: sistematizirano znanje i vještine koje se mogu prenositi podučavanjem, orijentacija prema pružanju usluga javnosti, postojanje strukovnih udruga i poštivanje profesionalne etike. ${ }^{1}$ Sve navedene značajke dugi niz godina sastavni su dio knjižničarske profesije i upravo zato knjižnice i knjižničari uživaju veliko povjerenje šire društvene zajednice svugdje u svijetu.

Važnost postojanja etičkih normi knjižničari su prepoznali davnih godina poštujući određena pravila i principe koje su im nudila strukovna uduženja, a prvi iskorak u tom smislu napravilo je američko knjižničarsko udruženje American Library Association (ALA) ${ }^{2}$. Članovi su formalnoadopted its first code of ethics in prihvatili svoj etički kodeks još 1939. godine, a kasnije su ih slijedila i mnoga druga udruženja širom svijeta. Kodeks je u međuvremenu doživio nekoliko izmjena, ali profesionalna etika knjižničara i dalje se temelji na poštivanju istih etičkih načela u odnosu prema korisnicima, kolegama i široj društvenoj javnosti. U odnosu prema korisnicima knjižničari primjenjuju načelo jednakosti u pružanju usluga, zalažu se za zaštitu privatnosti i slobodan pristup informacijama. U komunikaciji s kolegama dužni su graditi odnos međusobnog uvažavanja i poslovne suradnje, a

\footnotetext{
1 Vidi:Horvat, A. Profesionalizacija bibliotekarskog zanimanja. [citirano: 2018-07-07]. Dostupno na: http://dzs.ffzg.unizg.hr/text/horvat1.htm.

2 American Library Association. History of the Code of Ethics. [citirano: 2018-07-07]. Dostupno na: http://www.ala.org/Template.cfm?Section=History $1 \&$ Template=/ContentManagement/ ContentDisplay.cfm\&ContentID $=8875$.
} 
odnos prema javnosti uvjetovan je karakterom same knjižničarske profesije koja spada u djelatnosti od općeg društvenog interesa. Balansirajući između interesa javnog dobra i pojedinačnih političkih interesa vladajućih struktura, knjižničari poštivanjem normi svog etičkog kodeksa doprinose i ukupnoj profesionalizaciji ustanova u čijim se sastavima nalaze, narodnih i drugih knjižnica, obavljajući svoj posao na dobrobit svih građana. Štoviše, kao odgovorni profesionalci, sukladno svom poslanju i etičkim normama, knjižničari imaju obvezu poduzimati potrebne aktivnosti vezane uz unapređivanje života zajednice kojoj služe. Taj splet interakcijskih okolnosti koje knjižnicama i knjižničarima daju istovremenu odgovornost i obvezu prema široj društvenoj zajednici ne proizlazi samo iz institucionalnih i zakonodavnih odredbi kojima je regulirana djelatnost u pojedinim nacionalnim okvirima $^{3}$ već i iz univerzalnih etičkih vrijednosti koje imaju transnacionalni značaj i podrazumijevaju osobnu i profesionalnu predanost u radu za opće dobro. ${ }^{4} \mathrm{U}$ tom kontekstu američki profesor knjižničarstva R. David Lankes u svojoj nagrađivanoj knjizi The Atlas of new librarianship govoreći o misiji knjižničara polazi od stajališta da je osobna misija knjižničara kao stručnjaka profesionalca odvojena od misije knjižnice u kojoj je zaposlen. Osobna je misija vezana uz vrijednosti profesije, a to je po Lankesu razvoj društva kroz „kreiranje znanja“ u svojoj zajednici. ${ }^{5}$ Zagovaranje za knjižnice znači zagovaranje za vrijednosti knjižničarske profesije, u prvom redu otvoren i jednak pristup korisnicima, profesionalnu objektivnost i dostupnost informacija svim građanima, a potpora knjižnicama temelj je gospodarskog napretka i održivog razvoja općenito.

\section{Kako zagovarati knjižnice u javnosti?}

Javno zagovaranje relativno je nov pojam u Hrvatskoj i regionalnom okruženju koji se najčešće definira kao društveni proces čija je svrha postizanje određenih promjena od općeg interesa. Njegova upotreba uglavnom je bila vezana uz djelovanje nevladinih udruga u tranzicijskom razdoblju devedesetih godina, a tek početkom 2000. javno zagovaranje prihvaćeno je i od strane knjižničarske zajednice kao redovita aktivnost koja pomaže knjižničarima da u interesu svojih korisnika djeluju na donosioce odluka. Ako knjižničari žele uspješno zagovarati, važno je da spoznaju i prihvate svoju misiju te različitim aktivnostima senzibiliziraju širu društvenu zajednicu i tako usmjere javni fokus na knjižnice i njihove vrijednosti. Poznato je da su američke knjižnice i knjižničari vrlo aktivni u javnom

\footnotetext{
3 U Hrvatskoj je u zakonodavnom kontekstu knjižničarstvo normirano kao „djelatnost od interesa za Republiku Hrvatsku“. Vidi: Zakon o knjižnicama: pročišćeni tekst zakona: N.N. 105/97, 05/98, 104/00, 87/08, 69/09. // Zakon.hr. [citirano: 2018-10-10]. Dostupno na: https://www.zakon.hr/z/745/Zakon-o-knjižnicama.

${ }^{4}$ Lankes, D. R. The new librarianship: field guide. Cambridge, MA; London, England: MIT Press, 2016. Str. 65-67.

5 Lankes, D. R. The Atlas of new librarianship. Cambridge: MIT Press, 2011. Str. 23-29.
} 
zagovaranju, što je dio njihove tradicije, ali i zasluga knjižničarskih udruženja koja im omogućavaju dodatne edukacije za svladavanje potrebnih vještina. U tom smislu posebno se ističe American Library Association kao nacionalno udruženje koje objavljivanjem praktičnih priručnika dostupnih na mrežnim stranicama pruža stalnu podršku svojim članovima i potiče ih na organizirano djelovanje. U priručnicima se nude različiti alati javnog zagovaranja koji mogu biti od velike koristi i hrvatskim knjižničarima. ${ }^{6}$

Uloga javnih zagovarača pripada svima koji vjeruju u knjižnice i njihov značaj za razvitak informacijski pismenog i otvorenog društva, a za bilo koju vrstu javnog djelovanja svaka knjižnica mora imati ljude vješte u komunikaciji, prvenstveno iz svojih redova, ali isto tako i partnera pridruženih od strane korisnika i javnih djelatnika. Mnoge knjižnice osnivaju grupe potpore, ohrabruju ih i educiraju kako bi što glasnije u javnosti zastupale interese svojih korisnika. U skladu sa zagovaračkom tradicijom, svjetski poznate knjižnice poput Bodleian Library, čiji klub prijatelja Friends of the Bodleian ${ }^{7}$ djeluje još od 1925. godine, kao i male lokalne knjižnice, osnivaju svoje klubove prijatelja i pridaju im veliku važnost. ${ }^{8}$ Mnogi njihovi članovi nalaze se na ključnim društvenim pozicijama, imaju značajan utjecaj na donosioce odluka i, upravo zbog ranije spomenutog ugleda i povjerenja koje knjižnice uživaju u društvu, voljni su promicati ulogu knjižnica na svim razinama. U sastavu American Library Association djeluje i posebna sekcija pod nazivom United for Libraries : Association of Library Trustees, Advocates, Friends and Foundation ${ }^{9}$ osnovana 2009. godine kao specijalizirana partnerska mreža za podršku američkim knjižnicama. Sekcija je nastala spajanjem nekoliko srodnih grupacija čiji članovi smatraju da nema „snažnijih glasova za knjižnice“ od zajedničkog djelovanja onih koji knjižnice koriste, prikupljaju sredstva i upravljaju njima. Kod nas ima sličnih pokušaja, ali to još uvijek nije uobičajena praksa.. Možemo navesti primjer Društva Knjižničara u Splitu koje je 2000. godine osnovalo Klub prijatelja splitskih knjižnica. ${ }^{10}$ Prvi predsjednik Skupštine Kluba bio je akademik Ivo Petrinović, a ciljevi osnivanja bili su promocija knjižnica i njihove uloge u razvoju grada Splita, pronalaženje različitih oblika potpore za razvoj split-

\footnotetext{
6 Vidi: Frontline Advocacy Toolkit. [citirano: 2018-11-11]. Dostupno na: http://www.ala.org/ advocacy/frontline-advocacy-toolkit.

7 Vidi: Friends of the Bodleian. [citirano: 2018-11-11]. Dostupno na: https://www.bodleian. ox.ac.uk/bodley/friends/about.

8 Vidi više o tome: Bačić, E. Klubovi prijatelja knjižnica - uspješni zagovaratelji. // Vjesnik bibliotekara Hrvatske 48,1(2005), 73-82. [citirano: 2018-11-11]. Dostupno na: http://www.hkdrustvo.hr/vbh-arhiva/broj/89.

9 Vidi: United for libraries: Association of library trustees, advocates, friends and foundations. a division of the American Library Association. [citirano: 2018-11-11]. Dostupno na: http://www. ala.org/united/sites/ala.org.united/files/content/friends/orgtools/libraries-need-friends.pdf.

10 Vidi: Bačić, E. Društvo knjižničara u Splitu i lokalna zajednica. // Glasnik Društva bibliotekara Split 8(2010), 137-150.
} 
skih knjižnica, povezivanje programa splitskih knjižnica i informacijskih potreba lokalne zajednice i slobodan pristup informacijama. Klub je do 2013. godine bio aktivan uz redovito uključivanje svojih članova u različita studijska putovanja i posjete knjižnicama u organizaciji Društva knjižničara u Splitu.

U svojoj drugoj knjizi, namijenjenoj razumijevanju i zagovaranju strateške uloge knjižnica u razvoju društvene zajednice, Lankes ${ }^{11}$ navodi zanimljiv podatak da u SAD-u godišnje pet puta više građana posjeti javne knjižnice nego što ih prisustvuje utakmicama svih američkih košarkaških, bejzbolskih i hokejaških klubova. Podatak može poslužiti kao slikoviti orijentir o brojnosti potencijalnih zagovarača koji mogu pomoći u promoviranju knjižnica i njihovih vrijednosti. Mnogi književnici i javni djelatnici sustavno pružaju potporu knjižnicama i njihovim uslugama, poput Neila Gaimana, suradnika britanskih dnevnih novina The Guardian, koji u svojim popularnim javnim predavanjima o važnosti čitanja poručuje svim građanima da imaju obvezu reći političarima što žele i glasovati protiv političara bilo koje stranke koja ne razumije važnost čitanja u stvaranju vrijednih građana i onih političara koji ne žele djelovati u očuvanju i zaštiti znanja i poticanju pismenosti. Za Gaimana to nije stvar partijske politike, već interes cijelog čovječanstva. Neke od svojih poruka vezanih uz promociju knjižnica i njihovih vrijednosti Gaiman je nedavno publicirao u koautorstvu s ilustratorom Chrisom Riddellom. ${ }^{12}$

Osim spomenutih primjera dobre prakse, ističemo i važnost razvijanja dodatnih kompetencija knjižničara u smislu sustavnog angažmana u motiviranju većeg broja potencijalnih zagovarača iz šireg kruga društvene zajednice. Uključivanje korisnika, studenata, umirovljenika i drugih pripadnika u volonterske programe moguće je u svim tipovima knjižnica i jedan je od uspješnih načina komunikacije sa zajednicom. I u ovom slučaju možemo se poslužiti praktičnim primjerima iz američkih knjižnica ${ }^{13}$ koji se mogu primijeniti i u hrvatskim knjižnicama.

\section{Javno zagovaranje u Hrvatskoj i suradnja u regionalnom okruženju}

Knjižničarstvo se u zemljama hrvatskog regionalnog okruženja promatra kao visokoprofesionalna djelatnost koja uživa povjerenje javnosti i zakonski je re-

11 Lankes, D. R. Expect more: demanding better libraries for today's complex world. 2nd. ed. 2016. Str. 3. [citirano: 2018-12-12]. Dostupno na: https://expectmorelibrary.info/wp-content/ uploads/EMSecondEdition/ExpectMore2.pdf.

12 Neil Gaiman and Chris Riddell on why we need libraries - an essay in pictures. // The Guardian, September, 2018. [citirano: 2018-10-10]. Dostupno na: https://www.theguardian.com/ books/gallery/2018/sep/06/neil-gaiman-and-chris-riddell-on-why-we-need-libraries-an-essay-inpictures\#img-17.

13 Vidi: Library Volunteers welcome!: strategies for attracting, retaining and making the most of willing helpers / edited by C. Smallwood and L. Sanborn. Jefferson: McFarland \& Company, 2016. Str. $1-11$. 
gulirana, što je tradicija iz prethodnog sustava koju su knjižničari kao stručnjaci nastavili razvijati i u tranzicijskim vremenima. Po pitanju javnog zagovaranja knjižnica i knjižničarske profesije, iskustva su različita. U nekim sredinama strukovna društva tek su na početku sustavno organiziranih javnozagovaračkih aktivnosti, dok u nekim udruženjima djeluju za to posebno osnovane komisije i radna tijela, no definitivno se svi zalažu za javnu dimenziju profesionalnog djelovanja.

U tom smislu kao pozitivan primjer ističe se Hrvatsko knjižničarsko društvo (HKD) koje je javno zagovaranje za knjižnice usvojilo kao redovitu aktivnost Društva još 2003. godine. Iste godine osnovana je Radna grupa za javno zagovaranje knjižnica koja je kasnije prerasla u Komisiju za javno zagovaranje. Od tada do danas osnovna je zadaća Komisije upoznavanje što šireg kruga zainteresiranih knjižničara s osnovnim vještinama javnog zagovaranja. ${ }^{14}$ Kroz velik broj izlaganja održanih na različitim domaćim stručnim skupovima te uz posebno osmišljene radionice javnog zagovaranja u okviru Centra za stalno stručno usavršavanje knjižničara $(\mathrm{CSSU})^{15}$, u proteklih desetak godina više od tisuću knjižničara imalo je priliku upoznati se s osnovama javnog zagovaranja. U kurikulumu Centra radionice sastavni su dio Modula I: Intelektualna sloboda i pravna i etička pitanja knjižničarske profesije. ${ }^{16}$ Riječ je o radionicama Javno zagovaranje I i Javno zagovaranje II koje su namijenjene svim knjižničarima bez obzira na vrstu knjižnice ili godine radnog iskustva. Uz prvu radionicu koja se bavi osnovama javnog zagovaranja navodi se da polaznicima nije potrebno posebno predznanje, ali je korisno pohađati i radionice o vrijednostima knjižničarske profesije, zakonodavstvu i knjižničnoj statistici. U okviru radionice Javno zagovaranje II detaljnije se prikazuje način izrade i provedbe strategije javnog zagovaranja te se analizira dobra praksa javnozagovaračkog rada i izrada pojedinih akcijskih planova. Po odslušanim radionicama polaznici su u mogućnosti prepoznati važnost dokumentiranja dobre prakse i stvaranja baza podataka, izgradnje strateških odnosa i partnerstva u zajednici te važnost profesionalnog zajedništva i suradnje u nacionalnom, regionalnom i međunarodnom knjižničarskom okruženju. U namjeri da zainteresira širu hrvatsku javnost za značaj javnog djelovanja za potporu knjižnicama, HKD je 2014. godine u suradnji sa splitskom gradskom knjižnicom Marka Marulića organizirao 1. Okrugli stol o javnom zagovaranju. Svrha mu je bila potaknuti širu raspravu o važnosti zagovaranja za knjižnice, problematizirati neka pitanja vezana uz timski rad i partnerstvo te motivirati cjelokupnu knjižničarsku zajednicu na strateško promišljanje razvo-

14 Hrvatsko knjižničarsko društvo. Komisija za javno zagovaranje. [citirano: 2018-07-08]. Dostupno na: https://www.hkdrustvo.hr/hr/strucna_tijela/33/uvod/.

15 Centar za stalno stručno usavršavanje knjižničara. [citirano: 2018-07-08]. Dostupno na: http://cssu.nsk.hr/program-cssu-a-2018-godinu/.

16 Centar za stalno stručno usavršavanje knjižničara. Tečajevi. Modul I. [citirano: 2018-07-08]. Dostupno na: http://cssu.nsk.hr/tecajevi/modul-i-intelektualna-sloboda-i-pravna-i-eticka-pitanja-knjiznicarske-profesije/. 
ja knjižničarstva i usklađivanja knjižnične i srodne legislative kojom se regulira knjižnična djelatnost. Kroz dva tematska bloka vezana uz promicanje partnerstva u širem okruženju i stvaranje partnerstva u knjižničarskoj zajednici sudionici su pokušali pronaći odgovore na konkretna pitanja vezana uz doprinos knjižnica razvoju društva, ne samo kroz redovnu djelatnost i knjižnične usluge već i aktivnim sudjelovanjem u izgradnji civilnog društva. ${ }^{17}$ Zanimljivo je napomenuti da je u prvom tematskom bloku bila organizirana i panel-rasprava ,Suradnja knjižnica $i$ diplomatskih predstavnika u Republici Hrvatskoj“ u kojoj su sudjelovali počasni konzuli nekoliko europskih zemalja. Predstavili su mogućnosti za otvaranje novih prostora kulturne razmjene te ponudili podršku u organizaciji stručne suradnje s knjižnicama u inozemstvu. Potvrdu da je Hrvatsko knjižničarsko društvo bilo na pravom putu sa širokim spektrom svojih zagovaračkih aktivnosti danas nalazimo i u IFLA-inim promišljanjima vezanim uz strategiju javnog djelovanja. Jedan je od primjera i program Global vision ${ }^{18} \mathrm{u}$ kojem se ističe da se izazovi s kojima se danas suočavaju knjižnice mogu nadvladati samo inkluzivnim i globalnim odgovorom. U tom smjeru IFLA je motivirala tisuće knjižničara i prijatelja knjižnica da sudjeluju u IFLA-inoj raspravi Global Vision - pothvatu koji ima za cilj stvoriti zajednički globalni plan za pozicioniranje knjižnica u nacionalnim i međunarodnim okvirima. Trenutno u tom programu IFLA ima 213 aktivno uključenih zemalja i velik broj prikupljenih i zabilježenih ideja koje doprinose kolektivnoj viziji za budući razvoj knjižnica i knjižničarstva ${ }^{19}$.

Zagovaračke aktivnosti u okviru HKD-a od samog početka nastoje se provoditi sustavno, prema razrađenoj strategiji, s određenim ciljevima i prioritetima za određeno vremensko razdoblje. Prva Strategija javnog zagovaranja za knjižnice usvojena je 2008. godine te se odnosila na dvogodišnje razdoblje, a danas je na snazi Strategija javnog zagovaranja 2015.-2020. ${ }^{20}$ kojom se hrvatskim knjižničarima predlaže zagovaranje za knjižnice na lokalnoj, nacionalnoj, regionalnoj i međunarodnoj razini. Prije nekoliko godina Komisija je pokrenula i portal Imam pravo znati, imam pravo na knjižnicu ${ }^{21}$ s namjerom da potakne sustavnu razmjenu iskustava u zagovaranju između članova Hrvatskoga knjižničarskog društva, njihovih suradnika i partnera te izgradi bazu podataka o općinama i gradovima koji nemaju knjižnicu. Sadržaj tog portala usmjeren je i prema zakonodavnom zagovaranju kao jednoj od važnih aktivnosti u zaštiti profesije, pritom misleći

${ }_{17}$ Vidi: Bačić, E. ; A. Belan-Simić. Prvi okrugli stol o javnom zagovaranju za knjižnice i knjižničarstvo // HKD Novosti 63(2014). [citirano: 2018-07-07]. Dostupno na: https://www.hkdrustvo. $\mathrm{hr} / \mathrm{hkdnovosti/clanak/957.}$

18 IFLA Global Vision. [citirano: 2018-07-07]. Dostupno na: https://www.ifla.org/node/11900.

19 IFLA Global Vision Ideas store. [citirano: 2018-07-07]. Dostupno na: https://ideas.ifla.org/.

20 Hrvatsko knjižničarsko društvo. Strategija za javno zagovaranje HKD-a 2015-2020. [citirano: 2018-07-08]. Dostupno na: https://www.hkdrustvo.hr/hr/dokumenti/kategorija/ostalo/.

${ }^{21}$ Hrvatsko knjižničarsko društvo. Imam pravo znati, imam pravo na knjižnicu. [citirano: 201807-08]. Dostupno na: https://www.hkdrustvo.hr/hr/pravo_na_knjiznicu/10. 
na proces praćenja zakonskih normi vezanih uz reguliranje knjižničarske djelatnosti, što zahtijeva poseban istraživački i aktivistički angažman. Da je riječ o dugotrajnom procesu, potvrdilo se i nedavnim javnim aktivnostima članova Hrvatskog knjižničarskog društva vezanim uz rad na brojnim primjedbama na Prijedlog izmjena Zakona o knjižnicama ${ }^{22}$ čiji proces donošenja i usvajanja još nije završen.

Govoreći u kontekstu regionalne suradnje, možemo reći da su proteklih godina mnoga knjižničarska udruženja sustavno surađivala, knjižničari su gostovali na stručnim skupovima, postignuta je i vrlo dobra razina u razmjeni informacija s kolegama iz čitave regije na individualnoj razini, kao i na razini pojedinih knjižnica. Primjerice vrlo uspješna dugogodišnja suradnja pravnih i srodnih knjižnica 2008. godine rezultirala je formalnim udruživanjem u regionalnu mrežu Društva bibliotekara pravnih i srodnih biblioteka Jugoistočne Europe (South East European Association of Law and related Libraries - SEALL). ${ }^{23} \mathrm{Kad}$ govorimo o formalnim i neformalnim postignućima mreže, uglavnom mislimo na vrlo dobre osobne kontakte koje su knjižničari uspostavili s kolegama iz čitave regije, direktnu međuknjižničnu razmjenu i pretpostavke za mobilnost i partnerstvo. Partnerstvo je posebno ostvareno s gledišta zajedničkog djelovanja u okviru različitih IFLA-inih projekata. U tom smislu navodimo primjer projekta pod nazivom Regional cooperation: challenge and opportunity iz 2012. godine. Nosilac projekta bilo je Hrvatsko knjižničarsko društvo koje dobilo sredstva za promicanje regionalne suradnje knjižničarskih društava u okviru IFLA-ina posebnog fonda pod nazivom Building Strong Library Associations (BSLA) ${ }^{24}$ namijenjena jačanju utjecaja IFLA-e kroz osnaživanje nacionalnih knjižničarskih udruženja. ${ }^{25}$ Svrha projekta bila je profesionalni razvoj knjižničara, osobito u području zagovaračkih i upravljačkih vještina, te poticanje partnerstva i suradnje u razvoju zajedničkih regionalnih projekata na kontinuiranom profesionalnom razvoju knjižničara. U realizaciju projekta bile su uključene knjižničarske udruge iz Bosne i Hercegovine, Slovenije i Srbije.

\footnotetext{
22 Hrvatsko knjižničarsko društvo. Objava za medije - Novi Prijedlog zakona o knjižnicama štetan za razvoj društva. [citirano: 2018-12-12]. Dostupno na: https://www.hkdrustvo.hr/clanovi/ alib/datoteke/file/objava\%20za\%20medije \%20-\%20novi\%20Zakon $\% 20$ o\%20knji\%C5\%BEnicama $\% 20 \%$ C5\%A1tetan\%20za\%20razvoj\%20dru\%C5\%A1tva.pdf.

23 South East European Association of Law and related Libraries, [citirano: 2018-07-07]. Dostupno na: http://www.biblio-pravo.org/hr/.

24 Building strong library associations: impact report 2012. [citirano: 2018-09-09]. Dostupno na: https://www.ifla.org/files/assets/alp/BSLA/impact report/IFLA_BSLA_impactreport_2012.pdf.

25 Vidi: Project report: regional cooperation: challenge and opportunity, Croatian Library Association. [citirano: 2018-07-07]. Dostupno na: https://www.ifla.org/news/project-report-regional-cooperation-in-south-east-europe-challenge-and-opportunity-croatian.
} 


\section{IFLA-in Međunarodni program javnog zagovaranja i partnerstvo za održivi razvoj}

IFLA-in Međunarodni program javnog zagovaranja (International Advocacy Programme - IAP) ${ }^{26}$ novina je u izgradnji IFLA-inih strateških kapaciteta osmišljenih za potporu javnim zagovaračima prilikom promicanja važnosti uloge knjižnica za ostvarivanje ciljeva održivog razvoja. Taj program vezan je uz dugogodišnje IFLA-ine napore da knjižnice budu i službeno prepoznate od strane međunarodne zajednice kao važni partneri u provedbi UN-ove Agende 2030. Program je globalnog karaktera, s ciljem podizanja razine svijesti o ciljevima održivog razvoja i potrebnom angažmanu knjižničarskih djelatnika u lokalnoj zajednici, kao i na nacionalnoj i regionalnoj razini. U kontekstu međunarodnog programa zagovaranja, uključeni pojedinci osobno su se obvezali da će nastojati što više utjecati na donosioce odluka u svojim sredinama i poticati knjižničarske djelatnike i druge partnere na pojačani aktivizam vezano uz ostvarivanje ciljeva UN-ove Agende 2030. Važan je angažman u ostvarivanju svih 17 ciljeva održivog razvoja predviđenih Agendom, ali prateći IFLA-in blog s pregledom različitih međunarodnih zagovaračkih aktivnosti ${ }^{27}$ vidljivi su posebni IFLA-ini napori u dokumentiranju uloge knjižnica u ostvarivanju cilja broj 11 - Održivi gradovi i zajednice, posebno s gledišta uključivanja svih vrsta knjižnica u izgradnju koherentnih društava i očuvanje kulturne baštine.

Za razvoj i podizanje svijesti o važnosti vještina javnog zagovaranja IFLA je osmislila niz regionalnih radionica koje su se održavale tijekom 2016. i 2017. godine. Na trodnevnoj regionalnoj radionici za predstavnike europskih zemalja održanoj u Nizozemskoj 2016. godine sudjelovala su 24 predstavnika iz različitih vrsta knjižnica i knjižničarskih udruga iz 12 europskih zemalja. Radionica je pružila sudionicima potrebna znanja za strateško planiranje javnog zagovaranja i organiziranje akcija za podizanje svijesti u njihovim zemljama, kako bi se knjižnice što prije uključile u izradu nacionalnog razvojnog plana za implementaciju ciljeva UN-ove Agende 2030. Formiran je i europski tim u koji su uključene i hrvatske knjižničarke, članice HKD-a. ${ }^{28}$ Vezano uz spomenutu strategiju međunarodnog djelovanja, u kolovozu 2017. godine IFLA je objavila poziv za prijavu projekata za promoviranje i organizaciju nacionalnih i regionalnih aktivnosti za jačanje kapaciteta u provedbi UN-ove Agende. Na natječaj se javilo 75 projektnih predlagatelja iz cijelog svijeta, a među 14 odabranih bio je i projekt pod nazivom Unlocking the potential of Libraries in South-East Europe through Regional Co-

\footnotetext{
26 The International Advocay Programme (IAP). [citirano: 2018-07-07]. Dostupno na: https:// www.ifla.org/ldp/iap.

27 Vidi više o tome: Librarry policy and advocacy blog. [citirano: 2018-11-11]. Dostupno na: https://blogs.ifla.org/lpa/2018/02/07/libraries-and-the-un-in-2018/.

28 Na poziv IFLA-e za sudjelovanje u radionici i formiranju europskog tima u ime HKD-a uključile su se Edita Bačić i Davorka Pšenica.
} 
operation and Sustainable Development za koji se može reći da je jedan od važnijih rezultata postojeće regionalne suradnje. Nosilac je projekta Bibliotekarsko društvo Srbije, a partneri su Hrvatsko knjižničarsko društvo, Asocijacija informacijskih stručnjaka - bibliotekara, arhivista i muzeologa Bosne i Hercegovine (BAM) i South East European Association of Law and related Libraries (SEALL). Cilj tog regionalnog projekta jest zagovaranje za knjižnice na način da budu prepoznate kao vladini partneri uključeni u nacionalne razvojne planove za provedbu UN-ove Agende uz poseban naglasak na važnosti sustavnog dokumentiranja usluga u svim vrstama knjižnica koje svojim redovitim djelovanjem doprinose ostvarivanju ciljeva održivog razvoja, slično kao što to radi IFLA u okviru projekta Library Map of the World. ${ }^{29}$

Projekt se sastojao od tri radionice održane u Zagrebu, Beogradu i Mostaru u razdoblju od travnja do srpnja 2018., a rezultati su prezentirani na IFLA-inu Kongresu u Kuala Lumpuru kao poster-izlaganje voditeljica projekta. ${ }^{30} \mathrm{Na}$ prvoj radionici, održanoj u lipnju 2018. u Nacionalnoj i sveučilišnoj knjižnici u Zagre$\mathrm{bu}^{31}$, predstavljeni su zanimljivi rezultati ankete provedene među knjižničarima u Hrvatskoj, Srbiji i Bosni i Hercegovini. Većina anketiranih knjižničara prepoznala je ulogu knjižnica u ostvarivanju ciljeva održivog razvoja, naročito kroz svoje usluge koje se odnose na podršku kvaliteti obrazovanja, smanjenju svih vrsta nejednakosti, održivom razvoju gradova i zajednica, očuvanju sveukupnog prirodnog okoliša te poticanju suradnje i partnerstva prema svim ciljevima UN-ove Agende. Kao krajnji rezultat projekta predviđeno je i objavljivanje prikupljenih primjera dobre prakse zabilježenih za vrijeme trajanja projekta. To je aspekt o kojem treba voditi računa i u redovitoj praksi hrvatskih knjižnica gdje su postignuća u odnosu na suradnju sa zajednicom velika, događanja je puno, ali ne i dovoljno zabilježenih i dokumentiranih svjedočanstava o postignutim rezultatima. U tom smislu bilo bi korisno pratiti izdavačku praksu ALA-e koja putem svojih mrežnih izvora i različitih publikacija ${ }^{32}$ knjižničarima pruža podršku izborom praktičnih primjera, otvarajući tako prostor za argumentirano zagovaranje uloge knjižnica u osnaživanju zajednice kojoj služe. Ako uzmemo u obzir činjenicu da se kroz djelovanje

29 Vidi: Library Map of the World. Storytelling Manual. [citirano: 2018-07-07]. Dostupno na: https://librarymap.ifla.org/storytelling-manual.

30 Bačić, E.; D. Pšenica; V. Vuksan. Regional Library Cooperation for Implementation of UN Agenda 2030. // IFLA WLIC 2018 - Kuala Lumpur, Malaysia - Transform Libraries, Transform Societies in Session 153 - Poster Session.[citirano: 2018-10-10]. Dostupno na: http://library.ifla. org/2407.

31 Knjižnice kao partneri održivog razvoja - u NSK održana radionica o ulozi knjižnica u provođenju UN-ove strategije Agenda 2030. [citirano: 2018-10-10]. Dostupno na: http://www.nsk.hr/ knjiznice-kao-partneri-odrzivog-razvoja-u-nsk-odrzana-radionica-o-ulozi-knjiznica-u-provodenju-un-ove-strategije-agenda-2030/.

32 Vidi više o tome: ALA Products and Publications. [citirano: 2018-12-12]. Dostupno na: http:// www.ala.org/tools/publications. 
Ureda za udruge Vlade $\mathrm{RH}^{33}$ knjižničarskim udruženjima otvaraju nove mogućnosti za suradnju s državnim tijelima temeljene na brojnim projektima međunarodne suradnje i natječajima EU, korištenje evidence based argumantacije može biti od presudnog značaja. Danas, kad se u mnogim zemljama, u eri sve češćih kriznih političkih i gospodarskih situacija, redovito financiranje knjižnica dovodi u pitanje, dokazi postaju ključna komponenta zagovaranja. $\mathrm{O}$ toj se problematici posljednjih godina dosta raspravlja u međunarodnoj znanstvenoj i knjižničarskoj zajednici. U tom smislu zanimljivo je napomenuti da će važnost argumentacije temeljene na dokazima biti glavna tema konferencije koja će se održati u lipnju 2019. na Sveučilištu u Glasgowu (University of Strathclyde), a ima za cilj potaknuti praktičare $\mathrm{i}$ istraživače da razmisle o tome kako prikupljati dokaze i kako ih koristiti u ovim nesigurnim vremenima. ${ }^{34}$

\section{Zaključak}

Svrha usvajanja vještina javnog zagovaranja prvenstveno je vezana uz stvaranje uvjeta za što učinkovitije javno djelovanje knjižničara prilikom zastupanja interesa njihovih korisnika i interesa šire društvene zajednice. Kroz osmišljene programe potrebno je utjecati na podizanje svijesti o važnosti javnog zagovaranja kod pripadnika profesionalne zajednice i donosilaca odluka, da prepoznaju knjižnice ne samo kao mjesta važna za kulturu i učenje već i kao odgovorne i nezaobilazne partnere u razvoju društva općenito. Promatrano u globalnim okvirima, danas je to vrlo važno i s gledišta zagovaranja uloge knjižnica u implementaciji ciljeva UN-ove Agende 2030 za koju se zalaže cijela međunarodna zajednica, uključujući Republiku Hrvatsku. U radu se ukazuje i na potrebu sustavnog praćenja i dokumentiranja usluga u svim vrstama knjižnica koje svojim djelovanjem doprinose ostvarivanju ciljeva održivog razvoja. U tom smislu poželjno je partnersko udruživanje na lokalnoj, nacionalnoj, regionalnoj i međunarodnoj razini. Primjer uspješnog regionalnog partnerskog udruživanja u kontekstu suradnje za održivi razvoj u koju je uključeno i Hrvatsko knjižničarsko društvo svakako je projekt pod nazivom Unlocking the potential of Libraries in South-East Europe through Regional Cooperation and Sustainable Development. Projekt je prepoznat od strane IFLA-ina Međunarodnog programa javnog zagovaranja i tijekom 2018. godine proveden je uz inicijalnu financijsku potporu IFLA-e.

\footnotetext{
33 Vlada Republike Hrvatske. Ured za udruge. [citirano: 2018-07-07]. Dostupno na: https://udruge.gov.hr/.

34 Vidi: International Evidence Based Library and Information Practice Conference (EBLIP10). [citirano: 2018-12-12]. Dostupno na: https://www.eblip10.org/CallforPapers/tabid/8101/Default. aspx.
} 


\section{LITERATURA}

American Library Association. History of the Code of Ethics. [citirano: 2018-07-07]. Dostupno na: http://www.ala.org/Template.cfm?Section=History1\&Template=/ ContentManagement/ContentDisplay.cfm\&ContentID=8875.

Bačić, E. Klubovi prijatelja knjižnica - uspješni zagovaratelji. // Vjesnik bibliotekara Hrvatske 48,1(2005), 73-82. [citirano: 2018-11-11]. Dostupno na: http://www. hkdrustvo.hr/vbh-arhiva/broj/89.

Bačić, E.; A. Belan-Simić. Prvi okrugli stol o javnom zagovaranju za knjižnice i knjižničarstvo. // HKD Novosti 63(2014). [citirano: 2018-07-07]. Dostupno na: https:// www.hkdrustvo.hr/hkdnovosti/clanak/957.

Bačić, E.; D. Pšenica; V. Vuksan. Regional Library Cooperation for Implementation of UN Agenda 2030. // IFLA WLIC 2018 - Kuala Lumpur, Malaysia - Transform Libraries, Transform Societies in Session 153 - Poster Session.[citirano: 2018-10-10]. Dostupno na: http://library.ifla.org/2407.

Building strong library associations: impact report 2012. [citirano: 2018-09-09]. Dostupno na: https://www.ifla.org/files/assets/alp/BSLA/impact report/IFLA_BSLA_impactreport_2012.pdf.

Centar za stalno stručno usavršavanje knjižničara. [citirano: 2018-07-08]. Dostupno na: http://cssu.nsk.hr/program-cssu-a-2018-godinu/.

Centar za stalno stručno usavršavanje knjižničara. Tečajevi. Modul I. [citirano: 2018-0708]. Dostupno na: http://cssu.nsk.hr/tecajevi/modul-i-intelektualna-sloboda-i-pravna-i-eticka-pitanja-knjiznicarske-profesije/.

Friends of the Bodleian. [citirano: 2018-11-11]. Dostupno na: https://www.bodleian. ox.ac.uk/bodley/friends/about.

Horvat, A. Profesionalizacija bibliotekarskog zanimanja. [citirano: 2018-07-07]. Dostupno na: http://dzs.ffzg.unizg.hr/text/horvat1.htm.

Hrvatsko knjižničarsko društvo. Komisija za javno zagovaranje, [citirano: 2018-07-07]. Dostupno na: https://www.hkdrustvo.hr/hr/strucna_tijela/33/uvod/.

Hrvatsko knjižničarsko društvo. Objava za medije - Novi Prijedlog Zakona o knjižnicama štetan za razvoj društva. [citirano: 2018-10-10]. Dostupno na: https://www. hkdrustvo.hr/clanovi/alib/datoteke/file/objava\%20za\%20medije $\% 20-\% 20$ novi $\% 20$ Zakon\%20o\%20knji\%C5\%BEnicama\%20\%C5\%A1 tetan\%20za\%20razvoj\%20 dru\%C5\%A1tva.pdf.

Hrvatsko knjižničarsko društvo. Pravo na knjižnicu, [citirano: 2018-07-07]. Dostupno na: https://www.hkdrustvo.hr/hr/pravo_na_knjiznicu/10.

Hrvatsko knjižničarsko društvo. Strategija za javno zagovaranje HKD-a 2015.-2020. [citirano: 2018-07-08]. Dostupno na: https://www.hkdrustvo.hr/hr/dokumenti/kategorija/ostalo/.

IFLA Global Vision. [citirano: 2018-07-07]. Dostupno na: https://www.ifla.org/ node/11900. 
IFLA Global Vision Ideas store. [citirano: 2018-07-07]. Dostupno na: https://ideas.ifla.org/.

IFLA International Advocay Programme. [citirano: 2018-07-07]. Dostupno na: https:// www.ifla.org/ldp/iap.

Knjižnice kao partneri održivog razvoja - u NSK održana radionica o ulozi knjižnica u provođenju UN-ove strategije Agenda 2030. [citirano: 2018-10-10]. Dostupno na: http://www.nsk.hr/knjiznice-kao-partneri-odrzivog-razvoja-u-nsk-odrzana-radionica-o-ulozi-knjiznica-u-provodenju-un-ove-strategije-agenda-2030/.

International Evidence Based Library and Information Practice Conference (EBLIP10). [citirano: 2018-12-12]. Dostupno na:https://www.eblip10.org/CallforPapers/tabid/8101/Default.aspx.

Lankes, D. R. The Atlas of new librarianship, Cambridge: MIT Press, 2011.

Lankes, D. R. Expect more: demanding better libraries for today's complex world. 2nd ed. 2016.

Lankes, D. R. The New Librarianship: field guide. Cambridge, MA; London, England: The MIT Press, 2016.

Library Volunteers welcome!: strategies for attracting, retaining and making the most of willing helpers / ed. C. Smallwood and L. Sanborn. Jefferson: McFarland \& Company, 2016.

Library Map of the World. Storytelling Manual. [citirano: 2018-07-07]. Dostupno na: https://librarymap.ifla.org/storytelling-manual.

Library policy and advocacy blog. [citirano: 2018-11-11]. Dostupno na: https://blogs. ifla.org/lpa/2018/02/07/libraries-and-the-un-in-2018/.

Neil Gaiman and Chris Riddell on why we need libraries - an essay in pictures. // The Guardian. September, 2018, [citirano: 2018-10-10]. Dostupno na: https://www. theguardian.com/books/gallery/2018/sep/06/neil-gaiman-and-chris-riddell-on-whywe-need-libraries-an-essay-in-pictures\#img-17.

Project report: Regional cooperation: Challenge and opportunity, Croatian Library Association. [citirano: 2018-07-07]. Dostupno na: https://www.ifla.org/news/project-report-regional-cooperation-in-south-east-europe-challenge-and-opportunity-croatian.

South East European Association of Law and related Libraries. [citirano: 2018-07-07]. Dostupno na: http://www.biblio-pravo.org/hr/.

United for libraries: Association of library trustees, advocates, friends and foundations. a division of the American Library Association. [citirano: 2018-11-11]. Dostupno na: http://www.ala.org/united/sites/ala.org.united/files/content/friends/orgtools/libraries-need-friends.pdf.

Vlada Rrepublike Hrvatske. Ured za udruge. [citirano: 2018-07-07]. Dostupno na: https://udruge.gov.hr/.

Zakon o knjižnicama: pročišćeni tekst zakona: N.N. 105/97, 05/98, 104/00, 87/08, 69/09. // Zakon.hr. [citirano: 2018-10-10]. Dostupno na: https://www.zakon.hr/z/745/Zakon-o-knjižnicama. 